Bangladesh J. Plant Taxon. 21(1): 13-17, 2014 (June)

(C) 2014 Bangladesh Association of Plant Taxonomists

\title{
CYPSELAR DIVERSITY IN FOUR SPECIES OF SENECIO L. (ASTERACEAE)
}

\author{
Tulika Talukdar ${ }^{1}$ and Sobhan Kumar Mukherjee \\ Department of Botany, University of Kalyani, Kalyani, Nadia 741235, \\ West Bengal, India
}

Keywords: Senecio L.; Cypsela; Morphology; Pappus.

\begin{abstract}
The genus Senecio L. is one of the largest genera of flowering plants and is an important member of the tribe Senecioneae (Asteraceae). Phenotypic information, including a broad range of morphological characters is very crucial for phylogenetic reconsideration of any family, tribe or genus. In the family Asteraceae, very little attention has been paid to cypselar diversity, though it is regarded as taxonomically valuable. A sincere attempt has been made to study detailed cypselas macro and micromorphological features of four species of Senecio L. These diacritical features could be used to strengthen current inter-specific concept of Senecio L.
\end{abstract}

\section{Introduction}

The genus Senecio L. belongs to the tribe Senecioneae of the family Asteraceae and considered as one of the largest genera of flowering plants carrying c.1000 species in strict sense (Nordenstam, 2007). The taxonomic foundation of the tribe Senecioneae was initiated by Cassini, who distinguished 17 'natural tribes' including Senecioneae ("Les Senecionees") in his third Memoire (Cassini, 1816) of the tribal classification of "Synantherees" i.e. family Asteraceae. The tribe is traditionally characterized by an epaleate receptacle and a pappus of capillary bristles in their cypselas. Phylogenetically, the tribe is proposed by Small (1919) as the most primitive tribe of the family Asteraceae. On the other hand, due to its moderately large size manifested by tremendous number of species and genera [c. more than 3000 species in 151 genera by Nordenstam (2007)], almost cosmopolitan distribution and incredible morphological diversity, it is reconsidered as the evolutionary successful one (Bremer, 1994). Although DNA data provide the most reliable information for estimating evolutionary relationships and distances between taxa, these data alone cannot explain how or why a particular plant evolved without phenotypic information, including a broad range of morphological and chemical characters (Calabria et al., 2009). Therefore, a valid need of morphometric analysis cannot be ruled out.

It is really a fact that cypselar morphology in the family has not been received as much attention as it should be. According to Heywood et al. (1977), cypsela structure and anatomical features have been studied in details in only a few groups such as Anthemideae and Cardueae and found to be taxonomically valuable. They opined that "It is difficult to believe that carpological features will prove to be of lesser value in all the remaining tribes."

In this context, our present investigation deals with detailed studies of cypselas macro as well as micro-morphological features of four species of Senecio L., namely S. aegyptius L., S. alpinus (L.) Scop., S. aquaticus Hill. and S. viscosus L. of the tribe Senecioneae primarily using Light Microscope. Special emphasises have been given to traditional characters such as size and shape of cypselas, nature and distribution of ribs and furrows, nature of surface pubescence, structure of stylopodium, carpopodium, pappus etc. These diverse cypselar features could be utilized to construct an artificial key and to evaluate infra-generic phylogeny of Senecio.

${ }^{1}$ Department of Botany, A.P.C. Roy Govt. College, Siliguri, Darjeeling, West Bengal, India.

E-mail: talukdartulip12@gmail.com 


\section{Materials and Methods}

Plant materials (cypselas) for the present investigation were obtained from Hortus Botanicus Hauniensis, Denmark (DK) and Botanischer Garten der Universitat Zurich (Z).

\section{Macro-morphological studies of cypselas}

In cases, where intact cypselas were available, the first and foremost step was to mark the posterior and anterior surface of the cypselas. Then 10 dry and 10 FAA preserved mature cypselas were randomly taken in glass slides and graphed slides and observed under Olympus stereo dissecting microscope (DM) and Olympus binocular microscope (No. 611062). Suitable images were taken using Zeiss Stemi DV4 camera equipped microscope.

Shape and direction of cypselas were noted carefully. Length and width of the cypselas were measured visually by graphed slides, in few cases they were counted by ocular and stage micrometer. The length of the cypselas in the present study is defined as the length of the body of cypselas from basal meristematic zone (carpopodium) up to apical end excluding pappus. The width of the cypselas was measured at the widest part of the cypselar body.

\section{Micro-morphological studies of cypselas}

Mature cypselas were dipped in 1-5\% $\mathrm{NaOH}$ solution for 2-7 days depending upon the hardness. Then they were transferred into saturated chloral hydrate solution for few hours, repeatedly washed with water and properly stained in $0.2-0.5 \%$ aqueous Safranin solution. After staining, specimens were placed in $70 \%$ phenol glycerine solution and dissected carefully for studying different parts of cypselas. Suitable photographs were taken using Olympus C-310 zoom digital camera (3.2 Megapixel) and Zeiss-stereo microscope.

Nature of ribs, types, distribution and orientation of hairs, nature of surface cells, other epidermal structures and carpopodial cells were critically observed. Pappus characters such as

nature of pappus bristles, their number, arrangement, length and apex organization were also examined.

\section{Results and Discussion}

Cypselas of all the studied species (Figs 1\&2) are invariably homomorphic with a length ranging from 1.5 to $8.0 \mathrm{~mm}$. Cypselas are generally straight. Beside Senecio alpinus and $S$. aquaticus cypselas of other two species bear 7-10, prominent and straight ribs (Figs 1A,F,G, 2A). Pubescent cypselas have been noted except in S. alpinus (Fig. 1F). Hairs of all the pubescent species are of twin or duplex type, common in the family (Hess, 1938). They are typically threecelled, with two parallel cells and a smaller basal cell. Occurrence of few myxogenic hairs having mucilaginous properties when soaked in water have been reported by Nordenstam (1977), Konechaya (1981) and Mukherjee (2001) in the members of Senecioneae. Sahu (1983) has mentioned that these "Achenial hairs" has sharply pointed apex. In the contrary, Mukherjee (2001) has pointed out that "tips of the hairs are obtuse or rounded but not sharply pointed", as mentioned by Sahu (1.c.). Interestingly, in our observations both the statements are found to be true, as in Senecio aegyptius and S. viscosus tips of the hairs are sharply pointed (Figs 1C, 2B), while that of S. aquaticus are rounded (Fig. 1H).

Well-developed stylopodium with broaden base have been found in Senecio aquaticus (Fig. $1 \mathrm{G})$. In other studied species stylopodium is found to be ill-developed or insignificant.

Carpopodium is symmetric, either well-developed ring-like as found in Senecio viscosus (Fig. 2A), or ill-developed thickened band-like as in other three investigated species of Senecio. Carpopodium in all the studied taxa, is made up of rectangular, thick-walled cells arranged in several tangential rows. Such findings are well supported by Wetter (1983), who mentioned that in 
carpopodium of different members of Senecioneae "the squarish to rectangular (quadrate) cells were arranged in one to several rows or series. The number of rows which composed of carpopodium was constant in each species." Wetter (l.c.) also documented variation in the number of rows of cells among the species. This variation is also evident in the present observation, as the number of rows is 3-4 in Senecio viscosus and 1-2 in other three studied species. Haque and Godward (1984) have reported the absence of carpopodium in all four species of Senecio studied by them. But the present investigation is not in agreement with the above view, as carpopodium are found to be present in all the Senecio species studied.
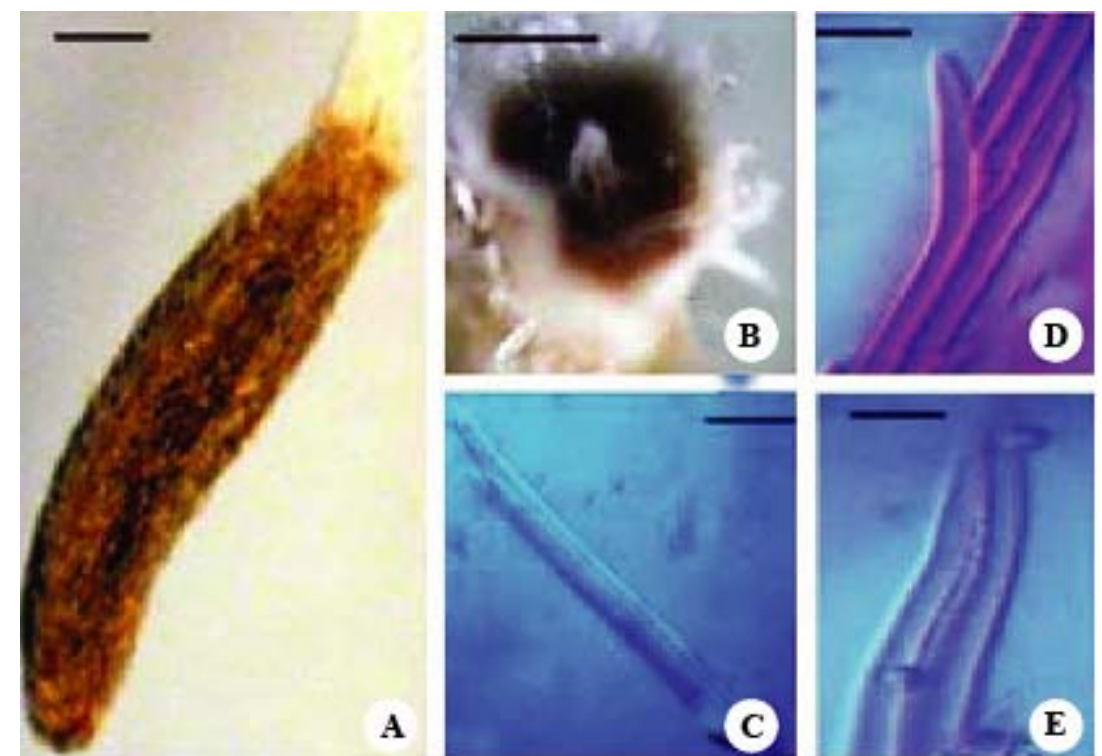

A
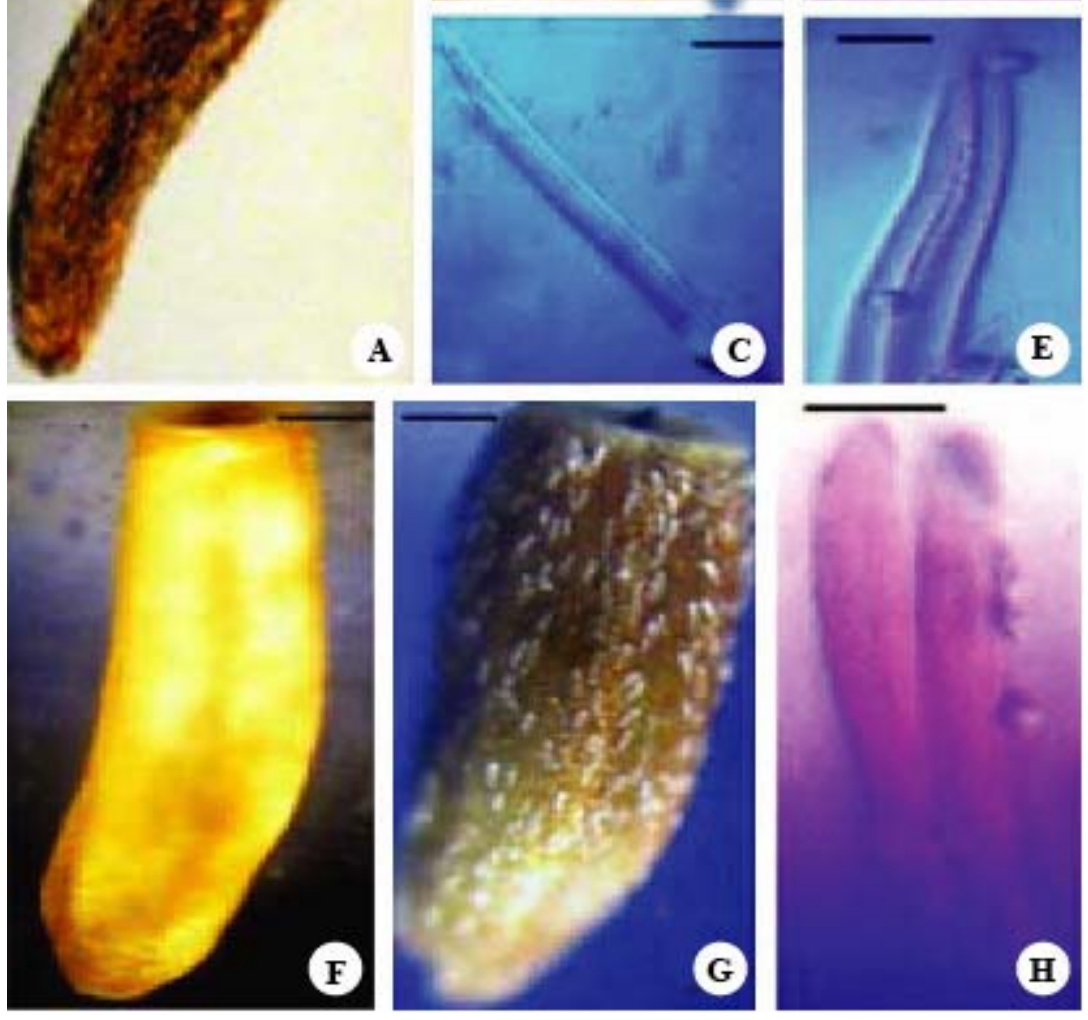

Fig. 1. Cypselar morphology of Senecio aegyptius (A-E), S. alpinus (F) and S. aquaticus (G-H). A, F, G. cypsela; B. apex with stylopodium; C, H. twin hair; D, E. parts of pappus bristle. Bar: $0.2 \mathrm{~mm}(\mathrm{~A}, \mathrm{~F}, \mathrm{G})$; $0.1 \mathrm{~mm}$ (B); $0.02 \mathrm{~mm}$; (C-E); $0.005 \mathrm{~mm}$ (H). 
Pappus usually represented by many, free, 2-5 mm long, persistent or caducous (as in Senecio aegyptius), scabrous or barbellate (as in S. aegyptius), biseriate bristles; with unequal, sharply pointed apical cells. Apical cells were two in number in S. aegyptius and three in S. viscosus (Figs $1 \mathrm{E}, 2 \mathrm{E})$. Biseriate pappus bristles of the genus Senecio have also been noted by Drury and Watson (1965), who mentioned that the outer series contain minute fimbrillae with retrorsely barbed tips called "fluked". However, our observation is not similar with the above view. Multiseriate pappus bristles also have been marked in Senecio viscosus. Often pappus bristles is reduced as in Senecio aquaticus, where pappus is represented by apical corona. So pappus with all its features can be employed in classification of taxa.
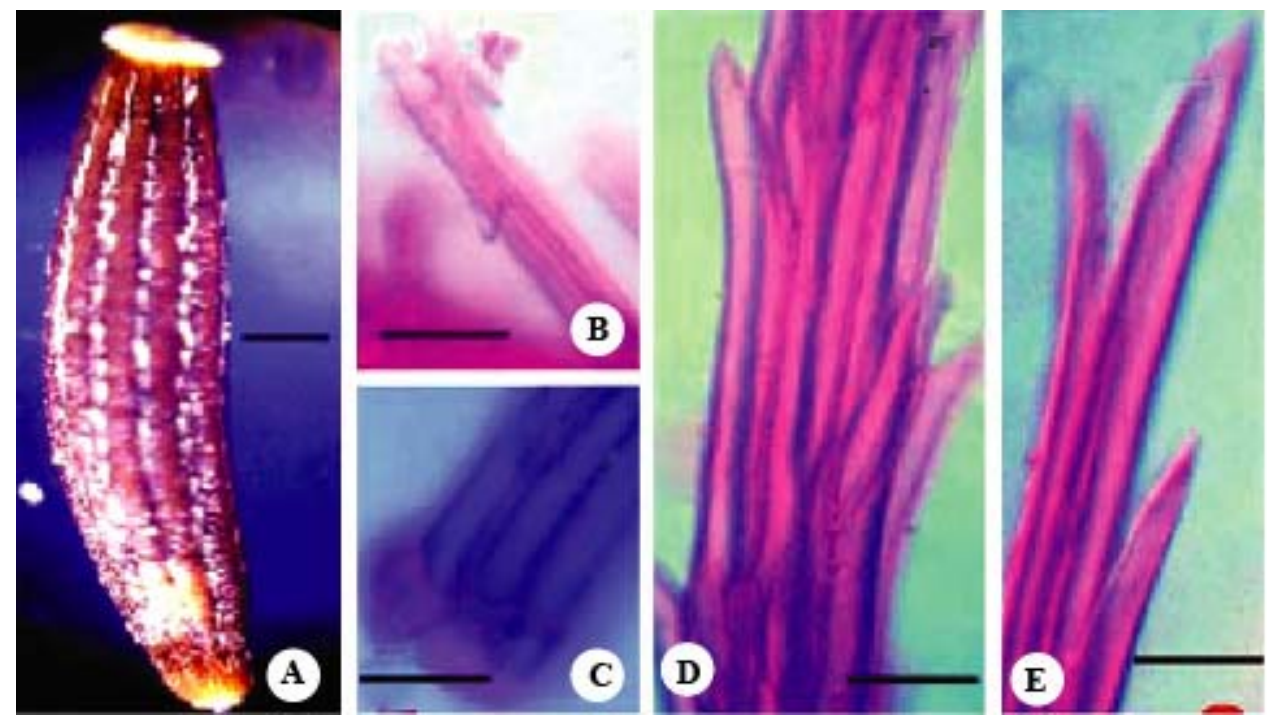

Fig. 2. Cypselar morphology of Senecio viscosus. A. cypsela; B. twin hair; C. base of pappus bristle; D. middle part of pappus bristle; E. apical part of pappus bristle. Bar: $0.2 \mathrm{~mm}$ (A); $0.02 \mathrm{~mm}$ (B-E).

Considering all these cypselar features, an attempt has been made to construct an artificial key to the species.

Key to the species of Senecio L.

1. Cypsela pubescent.

- Cypsela glabrous.

2. Cypsela truncate at the apex, quadrangular, not ribbed; stylopodium welldeveloped; insertion of cypsela oblique; pappus of apical corona.

- Cypsela rounded at the apex, cylindrical, 9-10 ribbed; stylopodium illdeveloped; insertion of cypsela straight; pappus of capillary bristles.

3. Stylopodium conical; carpopodium ill-developed, thickened band-like; pappus caducous, of biseriate barbellate bristles; apex of bristle made of two unequal cells.

S. aegyptius

- Stylopodium tubular; carpopodium well-developed, symmetric, circular ringlike; pappus persistent, of multiseriate scabrous bristles; apex of bristle made of three unequal cells. 
The present study on detailed macro- and micro-morphological features of cypselas of four species of Senecio L. is a preliminary attempt to assess the usefulness of cypsela as species delimiting factor. The analysis clearly indicates that in comparison to size and shape of cypsela, nature of carpopodium, presence or absence of rib, trichome tip, pappus features like arrangement of pappus bristle, number of apical cells in bristle etc. are much more reliable characters for interspecific grouping or separation.

\section{Acknowledgement}

We extend our special thanks to Dr. Hans Vilhelm Hansen, Curator, Denmark and to Dr. Peter Enz, Curator, Zurich for their active assistance in despatching the identified mature cypselas for our studies.

\section{References}

Bremer, K. 1994. Asteraceae. Cladistics and Classification. Timber Press, Portland.

Calabria, L.M., Emerenciano, V.P., Scott, M.T. and Mabry, T.J. (Eds). 2009. Secondary Chemistry of Compositae. In: Funk, V., Susanna, A., Stuessy, T.F. and Bayer, R.J. (Eds), Systematics, Evolution, and Biogeography of Compositae. Smithsonian Institution, Washington, DC., USA, pp. 369-383.

Cassini, H. 1816. In: King, R.M. and Dawson, H.W. (Eds), Cassini on Compositae, collected from the Dictionnaire des Sciences Naturelles. New York, Oriole Editions, pp. 535-602.

Drury, D.G. and Watson, L. 1965. Anatomy and the taxonomic significance of gross vegetative morphology in Senecio. New Phytol. 64: 307-314.

Haque, M.Z. and Godward, M.B.E. 1984. New records of the carpopodium in Compositae and its taxonomic use. Bot. J. Linn.Soc. 89: 321-340.

Hess, R. 1938. Vergleichende Untersuchungen uber die Zwillingshaare der Compositen. Bot. Jahrb. Syst. 68: 435-496.

Heywood, V.H., Harborne, J.B. and Turner, B.L. 1977. An overview to the Compositae. In: Heywood, V.H., Harborne, J.B. and Turner, B.L. (Eds), The Biology and Chemistry of the Compositae. Vol. 1. Academic Press, London, pp.780-802.

Konechaya, G.Y. 1981. Carpological and anatomical characters of species of the genus Senecio (Asteraceae) with reference to their taxonomy. Bot. Zh. (Leningr.) 66(6): 834-842.

Mukherjee, S.K. 2001. Cypselar features in nineteen taxa of the tribe Senecioneae (Asteraceae) and their taxonomic significance. In: Maheshwari, J.K. (Ed.), Recent Researches in Plant Anatomy and Morphology. Scientific Publishers, Jodhpur, India, pp. 253-274.

Nordenstam, B. 1977. Senecioneae and Liabeae - systematic review. In: Heywood, V.H., Harborne, J.B. and Turner, B.L. (Eds), The Biology and Chemistry of the Compositae. Vol. II. Academic Press, London, pp. 799-830.

Nordenstam, B. 2007 Senecioneae. In: Kadereit, J.W. and Jeffrey, C. (Eds), The Families and Genera of Vascular Plants. Vol. 8. Flowering Plants, Eudicots, Asterales. Springer, Berlin, pp. 208-241.

Sahu, T.R. 1983. Trichome studies in Senecio Linn: Structure, distribution and taxonomic significance. J. Indian Bot. Soc. 62: 84-89.

Small, J. 1919. The origin and development of the Compositae. V. The pappus. New Phytol. 11: 98-123.

Wetter, M.A. 1983. Micromorphological characters and generic delimitation of some New World Senecioneae (Asteraceae). Brittonia 35: 1-22. 